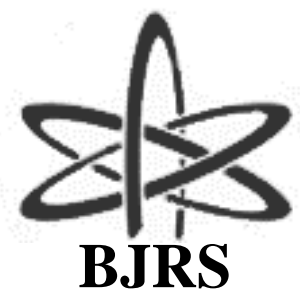

\author{
BRAZILIAN JOURNAL \\ $\mathrm{OF}$ \\ RADIATION SCIENCES \\ 09-02B (2021) 01-13
}

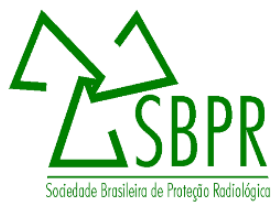

\title{
Effect of compaction pressure on the thermal conductivity of $\mathrm{UO}_{2}-\mathrm{BeO}-\mathrm{Gd}_{2} \mathrm{O}_{3}$ pellets
}

\author{
Denise das Mercês Camarano, Ana Maria Matildes Dos Santos, Fábio Abud Mansur \\ Centro de Desenvolvimento da Tecnologia Nuclear (CDTN/CNEN) \\ amms@cdtn.br
}

\begin{abstract}
The $(\mathrm{U}, \mathrm{Gd}) \mathrm{O}_{2}$ fuels are used in pressurized water reactors (PWR) to control the neutron population in the reactor during the early life with the purpose of extended fuel cycles and higher target burnups. Nevertheless, the incorporation of $\mathrm{Gd}_{2} \mathrm{O}_{3}$ in the $\mathrm{UO}_{2}$ fuel decreases the thermal conductivity, leading to premature fuel degradation. This is the reason for the addition of beryllium oxide (BeO), which has a high thermal conductivity and is chemically compatible with $\mathrm{UO}_{2}$. Pellets were obtained from powder mixtures of the $\mathrm{UO}_{2}, \mathrm{Gd}_{2} \mathrm{O}_{3}$ and BeO, being the oxide contents of the beryllium equal to 2 and $3 w t \%$, and the gadolinium fixed at $6 \mathrm{wt} \%$. The pellets were compacted at 400, 500, 600, and $700 \mathrm{MPa}$ and sintering under hydrogen reducing atmosphere. The purpose of this study was to investigate the effect of $\mathrm{BeO}, \mathrm{Gd}_{2} \mathrm{O}_{3}$ and compaction pressure on the thermal conductivity of the $\mathrm{UO}_{2}$ pellets. The thermal diffusivity and conductivity of the pellets were determined from $298 \mathrm{~K}$ to $773 \mathrm{~K}$ and the results obtained were compared to $\mathrm{UO}_{2}$ fuel pellets. The thermal diffusivity was determined by Laser Flash and Thermal Quadrupole methods and the thermal conductivity was calculated from the product of thermal diffusivity, the specific heat capacity and density. The sintered density of the pellets was determined by the xylol penetration and immersion method. The results showed an increase in the thermal conductivity of the pellets with additions of $\mathrm{BeO}$ and with the compaction pressure compared to the values obtained with $\mathrm{UO}_{2}$ pellets.
\end{abstract}

Keywords: thermal conductivity, nuclear fuel, uranium dioxide, beryllium oxide, gadolinium oxide 


\section{INTRODUCTION}

One of the most important limiting factors in water nuclear reactor operation is the maximum temperature reached by the fuel, being a higher thermal conductivity of fuel essential for improving reactor performance under normal operation and accident conditions. The $\mathrm{UO}_{2}$ pellet is most used fuel in LWR (light water reactor), but its low thermal conductivity in the range of $2-8 \mathrm{~W} \cdot \mathrm{m}^{-1} \cdot \mathrm{K}^{-1}[1]$ has a direct influence on the thermal behavior of the fuel during reactor operation as center fuel temperature, thermal expansion, fission gas release, gaseous swelling, etc.

Since there is a great interest in improving the thermal conductivity on nuclear fuel, several researches are being carried out with the addition of oxide to increase the thermal conductivity of the $\mathrm{UO}_{2}$ [2-7]. Researches to extent the fuel burnup are also conducted with the addition of oxide to $\mathrm{UO}_{2}$. These processes of oxide addition are generally based on the mechanical mixing process because it is an easy step to implement in the nuclear industry conventional of $\mathrm{UO}_{2}$ fuel.

Based on previous studies in the Nuclear Technology Development Center (CDTN) on the fuel compounds $\mathrm{UO}_{2}-\mathrm{BeO}$ and $\mathrm{UO}_{2}-\mathrm{Gd}_{2} \mathrm{O}_{3}$, the main additives employed here are $\mathrm{BeO}$ and $\mathrm{Gd}_{2} \mathrm{O}_{3}$, once the addition of small amounts of $\mathrm{BeO}$ significantly increases the fuel thermal conductivity [4,7] and $\mathrm{Gd}_{2} \mathrm{O}_{3}$ is widely used in the nuclear industry because it can compensate for the excess initial reactivity at the beginning of reactor life, promoting a higher fuel burnup [8,9].

However, the addition of $\mathrm{Gd}_{2} \mathrm{O}_{3}$ to $\mathrm{UO}_{2}$ leads to a decrease in the thermal conductivity of the fuel, making the amount of gadolinium oxide added a limiting parameter of the fuel performance $[8,9]$. Beryllium and gadolinium oxides have excellent properties as a high melting point, good behavior under irradiation, chemical stability, etc.

Ishimoto et al. [4] showed significant improvements in the thermal conductivity of $\mathrm{UO}_{2}$ that can be achieved with only 3.2 vol.\% of $\mathrm{BeO}$. Garcia et al. [6] demonstrated that $\mathrm{UO}_{2}$ thermal conductivity over the temperature range of $298.15 \mathrm{~K}$ to $523.15 \mathrm{~K}$ was improved by approximately $10 \%$ for each 1 vol. $\%$ of $\mathrm{BeO}$ added. Our research $[10,11]$ has shown that the addition of 2 and $3 \mathrm{wt} \%$ of $\mathrm{BeO}$ in $\mathrm{UO}_{2}$ can lead to an increase in the thermal conductivity of $22 \%$ and $28 \%$ at $573 \mathrm{~K}$, respectively.

The purpose of this paper is to investigate the effect of the compaction pressure on the thermal conductivity of the $\mathrm{UO}_{2}$ pellets added with $\mathrm{BeO}$ and $\mathrm{Gd}_{2} \mathrm{O}_{3}$. All pellets were obtained based on the conventional fabrication process, such as mixing, pressing, and sintering under a reducing 
atmosphere. The thermal diffusivity of the pellets was determined at $298 \mathrm{~K}$ by the Laser Flash method [12] and from $473 \mathrm{~K}$ to $773 \mathrm{~K}$ by the Thermal Quadrupole method [13]. The results for $\mathrm{UO}_{2}$ and $\mathrm{UO}_{2}-$ $\mathrm{BeO}-\mathrm{Gd}_{2} \mathrm{O}_{3}$ pellets such as density and thermophysical properties (thermal diffusivity, specific heat capacity and thermal conductivity) are reported. The expanded uncertainty was estimated according to the ISO/BIPM Guide to the Expression of Uncertainty in Measurement (GUM) [14].

\section{MATERIALS AND METHODS}

\subsection{Obtaining and pellets characterization}

The powders of $\mathrm{BeO}$ and $\mathrm{Gd}_{2} \mathrm{O}_{3}$ used in this work were supplied by Alfa Aesar (99.99\% pure) and Sigma-Aldrich (99.98\% pure), respectively, and the $\mathrm{UO}_{2}$ powder was provided by Institute of Energy and Nuclear Research (IPEN).

The $\mathrm{UO}_{2}$ and $\mathrm{UO}_{2}-\mathrm{BeO}-\mathrm{Gd}_{2} \mathrm{O}_{3}$ pellets were obtained by mixing of powders, pressing into green pellets and sintering under a hydrogen atmosphere. The powders of $\mathrm{UO}_{2}, \mathrm{BeO}$ and $\mathrm{Gd}_{2} \mathrm{O}_{3}$ were mechanically homogenized for $4 \mathrm{~h}$ in a rotating apparatus for each content of $\mathrm{BeO}(2 \%$ and $3 \mathrm{wt} \%)$ and $6 \mathrm{wt} \% \mathrm{Gd}_{2} \mathrm{O}_{3}$. These powders mixtures were compacted at 400, 500, 600, and $700 \mathrm{MPa}$ utilizing a uniaxial hydraulic press. Then, the green pellets were sintered at $1700{ }^{\circ} \mathrm{C}$ for $3 \mathrm{~h}$ and presented final geometric dimensions of about $10 \mathrm{~mm}$ in diameter and 2-3 $\mathrm{mm}$ in thickness.

The density of the sintered pellets was determined by xylol penetration and immersion method [15] and the mass of the pellets was taken using a Mettler AT201 balance, which has a resolution of $0.1 \mathrm{mg}$. The dependence of the sintered density of $\mathrm{UO}_{2}-\mathrm{BeO}-\mathrm{Gd}_{2} \mathrm{O}_{3}$ pellets with temperature was determined from linear thermal expansion data of the $\mathrm{UO}_{2}$.

\subsection{Thermophysical properties}

Thermal diffusivity of the pellets was determined by two methods: the Flash Laser [11] using an apparatus developed at CDTN [8] and the Thermal Quadrupole [13] employing a diffusivimeter (Protolab, QuadruFlash 1200), manufactured in Brazil. The Flash laser method was employed for measurements carried out at room temperature while the Thermal Quadrupole method was utilized in the temperature range of 473 to $773 \mathrm{~K}$. 
Before the measurements, the pellets were coated with a carbon film on both flat faces to improve the emissivity and uniform absorption of the laser beam. In both methods, the front surface of the pellets was subjected to a very short burst of radiant energy.

The thermal diffusivity results were normalized by the following equations [4]:

$$
\begin{aligned}
& \alpha_{95}=\alpha_{M}\left[\left(\frac{1-0,05 \cdot \varepsilon}{1-\varepsilon \cdot P}\right) \cdot\left(\frac{1-P}{1-0,05}\right)\right] \\
& \varepsilon=2.6-5 \times 10^{-4} \cdot(T-273.15)
\end{aligned}
$$

where $\alpha_{95}$ corresponds to the thermal diffusivity normalized to $95 \%$ of theoretical density (TD), $\alpha_{M}$ to the determined thermal diffusivity, $P$ to the pellet porosity and $T$ to the temperature.

The specific heat capacity values were calculated by the law of mixing [4] using reported data of specific heat of the individual components [16-18]. The thermal conductivity of fuel pellets was determined by product of their thermal diffusivity, density and specific heat capacity.

\section{RESULTS AND DISCUSSION}

Table 1 shows the geometric dimensions and sintered densities of the pellets for each compaction pressure. It can be observed from this table that the sintered density of the pellets was between $94 \%$ $\mathrm{TD}$ and $96 \% \mathrm{TD}$, exception for only one $\mathrm{UO}_{2}-6 \mathrm{wt} \% \mathrm{Gd}_{2} \mathrm{O}_{3}-3 \mathrm{wt} \% \mathrm{BeO}$ pellet pressed at $700 \mathrm{MPa}$. The maximum expanded relative uncertainty of sintered density pellets was estimated in $2 \%$, for a coverage probability of approximately $95 \%, \mathrm{k}=2$. Furthermore, there is an increase in the theoretical density of pellets with the increase compaction pressure. 
Table 1: Geometric dimensions and density of the sintered pellets related to compaction pressure.

\begin{tabular}{|c|c|c|c|c|c|}
\hline Pellet composition & $\begin{array}{c}\text { Compaction } \\
\text { pressure } \\
\text { (MPa) } \\
\end{array}$ & $\begin{array}{l}\text { Thickness } \\
\text { (cm) }\end{array}$ & $\begin{array}{l}\text { Diameter } \\
\quad(\mathrm{cm})\end{array}$ & $\begin{array}{c}\text { Sintered } \\
\text { Density } \\
\left(\mathrm{g} \cdot \mathrm{cm}^{-3}\right)\end{array}$ & $\% \mathrm{TD}$ \\
\hline \multirow{8}{*}{$\mathrm{UO}_{2}$} & \multirow{2}{*}{400} & 0.25 & 0.93 & 10.32 & 94 \\
\hline & & 0.24 & 0.93 & 10.34 & 94 \\
\hline & \multirow{2}{*}{500} & 0.24 & 0.94 & 10.36 & 95 \\
\hline & & 0.24 & 0.94 & 10.47 & 96 \\
\hline & \multirow{2}{*}{600} & 0.23 & 0.94 & 10.55 & 96 \\
\hline & & 0.23 & 0.94 & 10.56 & 96 \\
\hline & \multirow{2}{*}{700} & 0.23 & 0.96 & 10.54 & 96 \\
\hline & & 0.23 & 0.95 & 10.45 & 95 \\
\hline \multirow{8}{*}{$\mathrm{UO}_{2}+6 \mathrm{wt} \% \mathrm{Gd}_{2} \mathrm{O}_{3}+2 \mathrm{wt} \% \mathrm{BeO}$} & \multirow{2}{*}{400} & 0.26 & 0.94 & 9.50 & 94 \\
\hline & & 0.27 & 0.94 & 9.52 & 94 \\
\hline & \multirow{2}{*}{500} & 0.25 & 0.94 & 9.59 & 95 \\
\hline & & 0.26 & 0.94 & 9.67 & 96 \\
\hline & \multirow{2}{*}{600} & 0.25 & 0.95 & 9.65 & 95 \\
\hline & & 0.25 & 0.95 & 9.73 & 96 \\
\hline & \multirow{2}{*}{700} & 0.25 & 0.96 & 9.59 & 95 \\
\hline & & 0.25 & 0.97 & 9.59 & 95 \\
\hline \multirow{8}{*}{$\mathrm{UO}_{2}+6 \mathrm{wt} \% \mathrm{Gd}_{2} \mathrm{O}_{3}+3 \mathrm{wt} \% \mathrm{BeO}$} & \multirow{2}{*}{400} & 0.27 & 0.94 & 9.34 & 94 \\
\hline & & 0.27 & 0.94 & 9.33 & 94 \\
\hline & \multirow{2}{*}{500} & 0.26 & 0.94 & 9.45 & 96 \\
\hline & & 0.26 & 0.94 & 9.43 & 95 \\
\hline & \multirow{2}{*}{600} & 0.26 & 0.94 & 9.37 & 95 \\
\hline & & 0.26 & 0.95 & 9.40 & 95 \\
\hline & \multirow{2}{*}{700} & 0.26 & 0.96 & 9.24 & 93 \\
\hline & & 0.27 & 0.96 & 9.44 & 96 \\
\hline
\end{tabular}

The determined specific heat capacity of the pellets is presented in Table 2, where it can see an increase of the specific heat capacity of the pellets as a function of the $\mathrm{BeO}$ content, as expected. The expanded uncertainty adopted for the specific heat was assumed to be $2 \%$ [1].

Table 2: Specific heat capacity of the pellets.

\begin{tabular}{|c|c|c|c|c|c|}
\hline \multirow[t]{2}{*}{ Pellet composition } & \multicolumn{5}{|c|}{$\begin{array}{l}\text { Specific heat capacity } \\
\left(\mathbf{J} \cdot \mathrm{kg}^{-1} \cdot \mathbf{K}^{-1}\right)\end{array}$} \\
\hline & $298 \mathrm{~K}$ & $473 \mathrm{~K}$ & $573 \mathrm{~K}$ & $673 \mathrm{~K}$ & $773 \mathrm{~K}$ \\
\hline $\mathrm{UO}_{2}$ & 235 & 279 & 290 & 297 & 303 \\
\hline $\mathrm{UO}_{2}+2 \mathrm{wt} \% \mathrm{BeO}+6 \mathrm{wt} \% \mathrm{Gd}_{2} \mathrm{O}_{3}$ & 254 & 306 & 319 & 328 & 335 \\
\hline $\mathrm{UO}_{2}+3 \mathrm{wt} \% \mathrm{BeO}+6 \mathrm{wt} \% \mathrm{Gd}_{2} \mathrm{O}_{3}$ & 262 & 318 & 332 & 342 & 350 \\
\hline
\end{tabular}


Table 3 and Table 4 show thermal diffusivities as well as the thermal conductivities, both normalized to $95 \% \mathrm{TD}$ as a function of temperature for all compaction pressures. For these results, the expanded relative uncertainty was estimated at $7.5 \%$ for thermal diffusivity and $8.5 \%$ for thermal conductivity. It is known that the addition of gadolinia to $\mathrm{UO}_{2}$ decreases the thermal diffusivities and thermal conductivities [8], as observed in Table 3 and Table 4, respectively.

Table 3: Normalized thermal diffusivity of the pellets.

\begin{tabular}{|c|c|c|c|c|c|c|}
\hline \multirow[t]{2}{*}{ Pellet composition } & \multirow{2}{*}{$\begin{array}{c}\text { Compaction } \\
\text { pressure } \\
\text { (MPa) }\end{array}$} & \multicolumn{5}{|c|}{$\begin{array}{l}\text { Normalized thermal diffusivity } \\
\qquad\left(\mathrm{mm}^{2} \cdot \mathrm{s}^{-1}\right)\end{array}$} \\
\hline & & $298 \mathrm{~K}$ & $473 \mathrm{~K}$ & $573 \mathrm{~K}$ & $673 \mathrm{~K}$ & $773 \mathrm{~K}$ \\
\hline \multirow{8}{*}{$\mathrm{UO}_{2}$} & \multirow{2}{*}{400} & 2.87 & 2.02 & 1.73 & 1.58 & 1.42 \\
\hline & & 2.88 & 1.98 & 1.69 & - & - \\
\hline & \multirow{2}{*}{500} & 2.79 & 1.99 & 1.68 & 1.52 & 1.37 \\
\hline & & 2.73 & 1.95 & 1.67 & 1.51 & - \\
\hline & \multirow{2}{*}{600} & 2.79 & 1.91 & 1.65 & 1.51 & 1.34 \\
\hline & & 2.74 & - & - & - & - \\
\hline & \multirow{2}{*}{700} & 2.74 & 1.98 & 1.78 & 1.61 & 1.44 \\
\hline & & 2.78 & - & - & - & - \\
\hline \multirow{8}{*}{$\mathrm{UO}_{2}+2 \mathrm{wt} \% \mathrm{BeO}+6 \mathrm{wt} \% \mathrm{Gd}_{2} \mathrm{O}_{3}$} & \multirow{2}{*}{400} & 2.14 & 1.68 & 1.46 & 1.39 & 1.28 \\
\hline & & 2.23 & 1.69 & 1.51 & 1.38 & 1.30 \\
\hline & \multirow{2}{*}{500} & 2.19 & 1.71 & 1.48 & 1.36 & 1.23 \\
\hline & & 2.17 & - & - & - & - \\
\hline & \multirow{2}{*}{600} & 2.14 & 1.71 & 1.47 & 1.34 & 1.27 \\
\hline & & 2.13 & - & - & - & - \\
\hline & \multirow{2}{*}{700} & 2.19 & 1.65 & 1.49 & 1.32 & 1.27 \\
\hline & & 2.16 & - & - & - & - \\
\hline \multirow{8}{*}{$\mathrm{UO}_{2}+3 \mathrm{wt} \% \mathrm{BeO}+6 \mathrm{wt} \% \mathrm{Gd}_{2} \mathrm{O}_{3}$} & \multirow{2}{*}{400} & 2.35 & 1.74 & 1.53 & 1.44 & 1.36 \\
\hline & & 2.34 & 1.73 & 1.57 & 1.46 & 1.34 \\
\hline & \multirow{2}{*}{500} & 2.29 & 1.69 & 1.52 & 1.41 & 1.29 \\
\hline & & 2.31 & - & - & - & - \\
\hline & \multirow{2}{*}{600} & 2.34 & 1.77 & 1.55 & 1.48 & 1.35 \\
\hline & & 2.30 & - & - & - & - \\
\hline & \multirow{2}{*}{700} & 2.69 & 2.00 & 1.71 & 1.62 & 1.46 \\
\hline & & 2.56 & - & - & - & - \\
\hline
\end{tabular}


Table 4: Normalized thermal conductivity of the pellets.

\begin{tabular}{|c|c|c|c|c|c|c|}
\hline \multirow[t]{2}{*}{ Pellet composition } & \multirow{2}{*}{$\begin{array}{l}\text { Compaction } \\
\text { pressure } \\
\text { (MPa) }\end{array}$} & \multicolumn{5}{|c|}{$\begin{array}{l}\text { Normalized thermal conductivity } \\
\qquad\left(\mathbf{W} \cdot \mathbf{m}^{-1} \cdot \mathbf{K}^{-1}\right)\end{array}$} \\
\hline & & $298 \mathrm{~K}$ & $473 \mathrm{~K}$ & $573 \mathrm{~K}$ & $673 \mathrm{~K}$ & $773 \mathrm{~K}$ \\
\hline \multirow{8}{*}{$\mathrm{UO}_{2}$} & \multirow{2}{*}{400} & 6.97 & 5.79 & 5.14 & 4.80 & 4.38 \\
\hline & & 7.00 & 5.70 & 5.03 & - & - \\
\hline & \multirow{2}{*}{500} & 6.81 & 5.73 & 5.00 & 4.62 & 4.24 \\
\hline & & 6.73 & 5.68 & 5.02 & 4.65 & - \\
\hline & \multirow{2}{*}{600} & 6.93 & 5.59 & 5.02 & 4.68 & 4.24 \\
\hline & & 6.80 & - & - & - & - \\
\hline & \multirow{2}{*}{700} & 6.78 & 5.79 & 5.40 & 5.00 & 4.54 \\
\hline & & 6.82 & - & - & - & - \\
\hline \multirow{8}{*}{$\mathrm{UO}_{2}+2 \mathrm{wt} \% \mathrm{BeO}+6 \mathrm{wt} \% \mathrm{Gd}_{2} \mathrm{O}_{3}$} & \multirow{2}{*}{400} & 5.18 & 4.86 & 4.40 & 4.29 & 4.02 \\
\hline & & 5.41 & 4.88 & 4.55 & 4.26 & 4.10 \\
\hline & \multirow{2}{*}{500} & 5.33 & 5.00 & 4.50 & 4.24 & 3.90 \\
\hline & & 5.33 & - & - & - & - \\
\hline & \multirow{2}{*}{600} & 5.24 & 5.01 & 4.48 & 4.21 & 4.05 \\
\hline & & 5.26 & - & - & - & - \\
\hline & \multirow{2}{*}{700} & 5.34 & 4.83 & 4.52 & 4.11 & 4.04 \\
\hline & & 5.26 & - & - & - & - \\
\hline \multirow{8}{*}{$\mathrm{UO}_{2}+3 \mathrm{wt} \% \mathrm{BeO}+6 \mathrm{wt} \% \mathrm{Gd}_{2} \mathrm{O}_{3}$} & \multirow{2}{*}{400} & 5.74 & 5.15 & 4.70 & 4.55 & 4.40 \\
\hline & & 5.70 & 5.11 & 4.84 & 4.61 & 4.33 \\
\hline & \multirow{2}{*}{500} & 5.68 & 5.05 & 4.75 & 4.50 & 4.22 \\
\hline & & 5.72 & - & - & - & - \\
\hline & \multirow{2}{*}{600} & 5.74 & 5.24 & 4.80 & 4.69 & 4.38 \\
\hline & & 5.66 & - & - & - & - \\
\hline & \multirow{2}{*}{700} & 6.51 & 5.85 & 5.22 & 5.08 & 4.67 \\
\hline & & 6.33 & - & - & - & - \\
\hline
\end{tabular}

Results of normalized thermal conductivity of the pellets pressed at $400 \mathrm{MPa}$ were in the range from 7.00 up to $4.38 \mathrm{~W} \cdot \mathrm{m}^{-1} \cdot \mathrm{K}^{-1}$ for $\mathrm{UO}_{2}$; from 5.41 up to $4.02 \mathrm{~W} \cdot \mathrm{m}^{-1} \cdot \mathrm{K}^{-1}$ for $\mathrm{UO}_{2}-2 \% \mathrm{BeO}-6 \% \mathrm{Gd}_{2} \mathrm{O}_{3}$ and from 5.74 up to $4.33 \mathrm{~W} \cdot \mathrm{m}^{-1} \cdot \mathrm{K}^{-1}$ for $\mathrm{UO}_{2}-3 \% \mathrm{BeO}-6 \% \mathrm{Gd}_{2} \mathrm{O}_{3}$ throughout the measured temperature range. The highest percentage deviation from normalized thermal conductivity of the pellets of the same composition pressed at $400 \mathrm{MPa}$ in relation to other compactions pressures was $5 \%$. Only for pellets with $3 \mathrm{wt} \% \mathrm{BeO}$ pressed at $700 \mathrm{MPa}$ showed a deviation higher than 14\%. An increase of only $1 \mathrm{wt} \%$ in $\mathrm{BeO}$ in the case of pellets pressed at $400 \mathrm{MPa}$ caused an increase in normalized thermal conductivity measured at room temperature and up to $773 \mathrm{~K}$ by $8 \%$ and $5 \%$, respectively. Table 4 
also includes some results of the replicated pellets which indicated a good reproducibility of the process of obtaining pellets.

Characteristic graphs of thermal conductivities are shown from Fig. 1 to Fig. 3, where it can be seen there is a gradual increase of the thermal conductivity with increasing $\mathrm{BeO}$ content and a decrease in these values with increasing temperature that followed the same trend observed for thermal diffusivity not shown here.

Figure 1: Normalized thermal conductivity of $95 \% \mathrm{TD}$ of $\mathrm{UO}_{2}$ pellets in function of the compaction pressure.

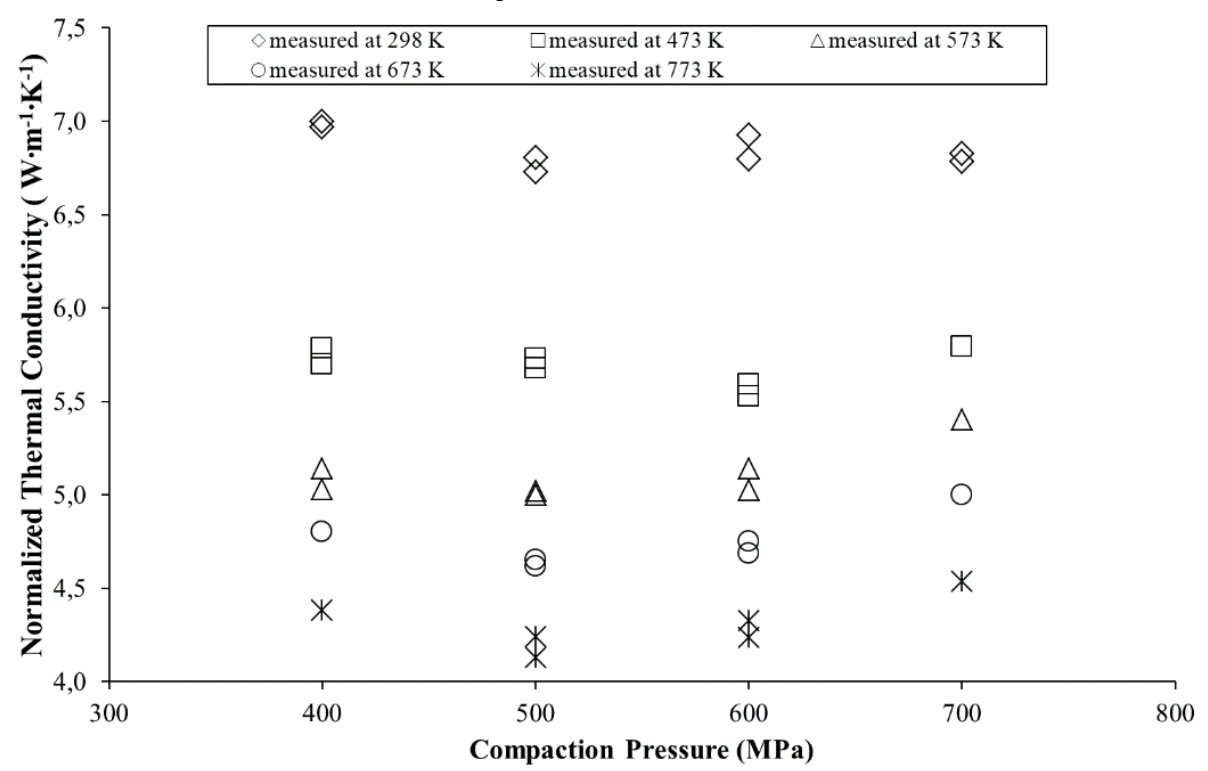


Figure 2: Normalized thermal conductivity of $95 \%$ TD of $\mathrm{UO}_{2}-2 \% \mathrm{BeO}-6 \% \mathrm{Gd}_{2} \mathrm{O}_{3}$ pellets in function of the compaction pressure.

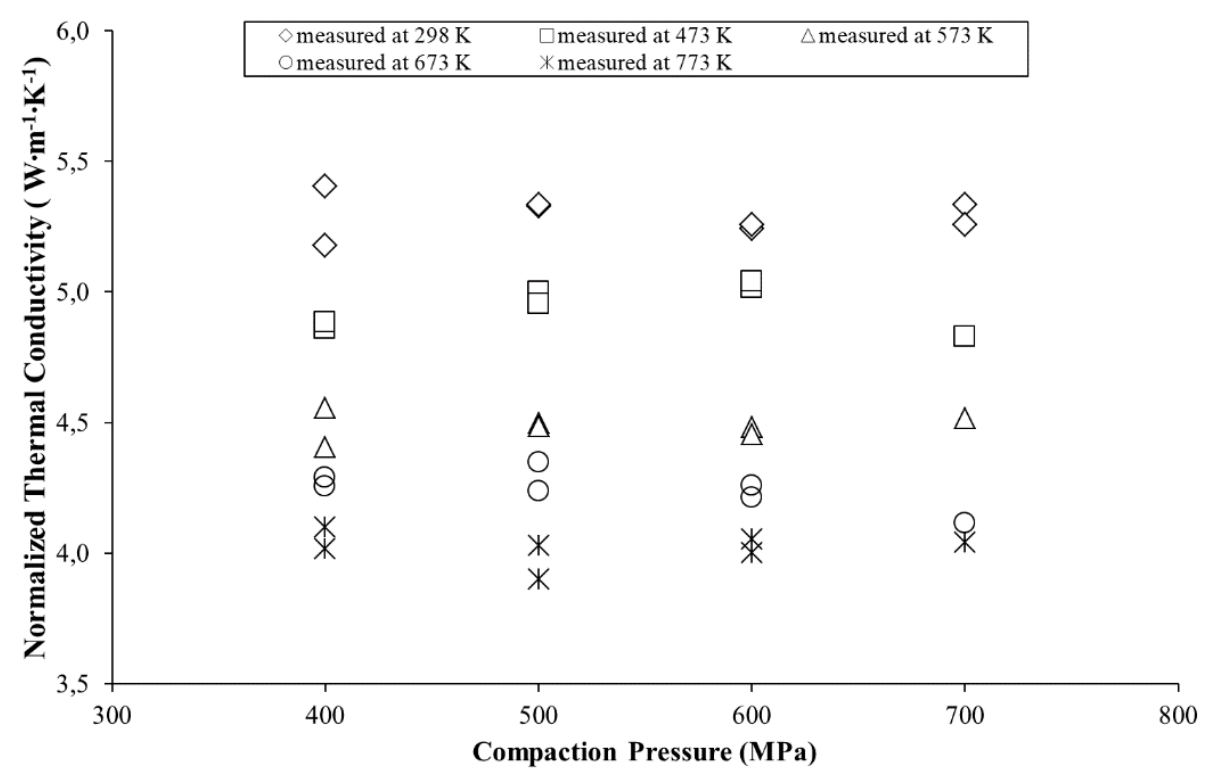

Figure 3: Normalized thermal conductivity of $95 \%$ TD of $\mathrm{UO}_{2}-3 \% \mathrm{BeO}-6 \% \mathrm{Gd}_{2} \mathrm{O}_{3}$ pellets in function of the compaction pressure.

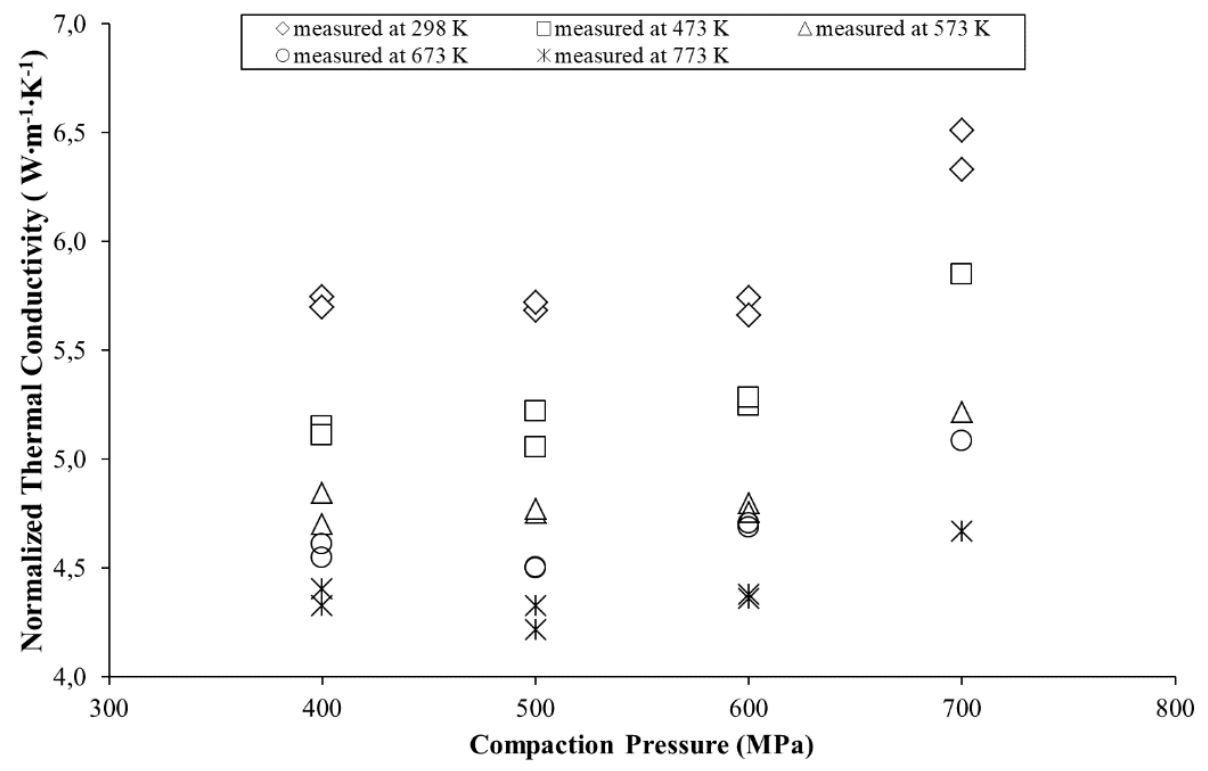




\section{CONCLUSION}

To improve the performance of nuclear fuel, the thermal conductivity of $\mathrm{UO}_{2}$ pellets was investigated with the incorporation of additives in the form of beryllium and gadolinium oxides. In addition to the beryllium content, the compaction pressures of the $\mathrm{UO}_{2}$ and $\mathrm{UO}_{2}-\mathrm{xBeO}-6 \mathrm{Gd}_{2} \mathrm{O}_{3}$ pellets $(\mathrm{x}=1 \mathrm{wt} \%$ and $2 \mathrm{wt} \%)$ varied from 400 to $700 \mathrm{MPa}$. The additions of $\mathrm{Gd}$ and $\mathrm{Be}$ had the objective of prolonging the burnup time of $\mathrm{UO}_{2}$ and attenuating the decrease in the thermal conductivity of $\mathrm{UO}_{2}$ caused by the presence of gadolinium, respectively. The comparison between the values of thermal conductivity obtained in the pellets with mixed oxide to $\mathrm{UO}_{2}$ for all compaction pressures indicated that $\mathrm{BeO}$ increased the thermal conductivity and between pressures of 500 and $700 \mathrm{MPa}$ there was no the significative difference. There is an increase in thermal conductivity from $8 \%$ at room temperature and $5 \%$ up to $773 \mathrm{~K}$, for the compaction pressure of $400 \mathrm{MPa}$ considering the temperature range measured when comparing insert data with 2 and $3 \%$ by weight of $\mathrm{BeO}$. 


\section{ACKNOWLEDGMENT}

The authors thank the financial support of Sistema Brasileiro de Tecnologia (Sibratec-ModernitSisNANO).

\section{REFERENCES}

[1] IAEA - International Atomic Energy Agency. Thermophysical Properties Database of materials for light water reactors and heavy water reactor. IAEA TECDOC-1496, Vienna: IAEA, 2006. 397p.

[2] SOLOMON A. A.; REVANKAR S.; McCOY J. K. Enhanced Thermal Conductivity Conductivity Oxide Fuels, Purdue University School of Nuclear Engineering. West Lafayette, Indiana, USA. 2006. Available at: <https://www.osti.gov/biblio/862369-iDA0bI/>. Last accessed: 21 May 2020.

[3] BUCKLEY J.; TURNER J. D.; ABRAM T. J. Uranium Dioxide-Molybdenum Composite Fuel Pellets with enhanced Thermal Conductivity Manufactured Via Spark Plasma Sintering. J Nuclear Mat, v. 523, p. 360-368, 2019.

[4] ISHIMOTO S.; HIRAI M.; ITO K.; KOREI Y. Thermal Conductivity of $\mathrm{UO}_{2}$-BeO Pellet. J Nuc Sci Tech, v. 33:2, p 134-140, 1996.

[5] MASSIH A. R. Effects of Additives on Uranium Dioxide Behavior, Swedish Radiation Safety Authority. Uppsala, Sweden. 2014. Available at:

<https://www.stralsakerhetsmyndigheten.se/contentassets/af14180bb6a94795a26c233fd4351d7 b/201421-effects-of-additives-on-uranium-dioxide-fuel-behavior> Last accessed: 21 May 2020.

[6] McCOY K.; MAYS C. Enhanced Themal Conductivity Oxide Nuclear Fuels by Co-sintering with BeO: II. Fuel Perfomance and Neutronics. J Nuc Materials, v. 375, p. 157-167, 2008. 
[7] GARCiA C. B.; BRITTO R. A.; ORTEGA L. H.; MAlONE J. P.; McDEAVITT S. M. Manufacture of a $\mathrm{UO}_{2}$-Based Nuclear Fuel with Improved Thermal Conductivity with the Addition of BeO. Met and Mat Transactions E, v. 76, p. 70-76, 2017.

[8] HIRAI M. Thermal diffusivity of $\mathrm{UO}_{2}-\mathrm{Gd}_{2} \mathrm{O}_{3}$ Pellets, J Nuc Mat, v. 173, p. 247-254, 1990.

[9] IWASAKI K. et al. Thermal Conductivity of $\mathrm{Gd}_{2} \mathrm{O}_{3}$-dispersed $\mathrm{UO}_{2}$ pellet, In: ATALANTE, 2008, Montpellier. Annals of Atalante 2008. Montpellier: French Alternative Energies and Atomic Energy Commission, 2008. Available at:

<https://inis.iaea.org/collection/NCLCollectionStore/_Public/40/034/40034680.pdf>

Last accessed: 21 May 2020.

[10] CAMARANO D. M.; MANSUR F. A.; SANTOS A. M. M.; FERRAZ W. B.; FERREIRA R. A. N. Effects of Beryllium and Compaction Pressure on the Thermal Diffusivity of Uranium Dioxide Fuel Pellets. Int. J. Thermophys, v 38:137, 2017.

[11] CAMARANO D. M.; MANSUR F. A.; SANTOS A. M. M.; FERRAZ W.B.; FERREIRA R. A. N. Thermal Conductivity and Thermal Diffusivity of $\mathrm{UO}_{2}-\mathrm{BeO}$ Nuclear Fuel Pellets", In: INTERNATIONAL NUCLEAR ATLANTIC CONFERENCE, 2017, Belo Horizonte. Annals of INAC 2017. Belo Horizonte: Comissão Nacional de Energia Nuclear, 2017.

[12] ASTM - American Society for Testing and Materials. Standard Test Method for Thermal Diffusivity by the Flash Method. ASTM E1461, West Conshohocken, Palo Alto: ASTM, 2013. 11p.

[13] DEGIOVANNI A.; MAIllet D.; ANDRÉ S.; BATSALE J. C.; MOYNE C. Thermal Quadrupoles - Solving the Heat Equation Through Integral Transform, $1^{\text {st }}$ ed. London: Wiley, 2000.

[14] JCGM - Joint Committee for Guides in Metrology Evaluation of measurement data. Guide to the Expression of Uncertainty in Measurement. JCGM 100:2008, Sèvres, Paris: JCGM, 2008. 120p. Available at:

<https://www.bipm.org/utils/common/documents/jcgm/JCGM_100_2008_E.pdf>.

Last accessed: 21 May 2020. 
[15] ASTM - American Society for Testing and Materials. Standard Test Methods for Density of Compacted or Sintered Powder Metallurgy (PM) Products Using Archimedes' Principle. ASTM B962, West Conshohocken, Palo Alto: ASTM, 2017. 7p.

[16] IAEA - International Atomic Energy Agency. Thermo-physical Materials Properties Database. IAEA-THERPRO, Seoul: IAEA, 2010. Available at: <http://therpro.hanyang.ac.kr>. Last accessed: 21 May 2020.

[17] IAEA - International Atomic Energy Agency. Thermophysical Properties of Materials for Nuclear Engineering: A Tutorial and Collection of Data. IAEA-THPH, Vienna: IAEA, 2008. 191p. Available at: <http://www-pub.iaea.org/MTCD/Publications/PDF/IAEATHPH_web.pdf>. Last accessed: 21 May 2020.

[18] Krishnan R. V.; PANNEERSElVAM G.; MANIKANDAN P.; ANTONY M. P.; NAGARAJAN K. Heat Capacity and Thermal Expansion of Uranium-Gadolinium Mixed Oxide. J Nuc Radiochem Sci, v. 10, p. 19-26, 2009. 